\title{
Treatment with captopril abrogates the altered expression of alpha1 macroglobulin and alpha1 antiproteinase in sera of spontaneously hypertensive rats
}

Norhaniza Aminudin ${ }^{1,2^{*}}$, Nur-Atiqah H Abdullah', Hasni Misbah³, Saiful A Karsani ${ }^{1,2}$, Ruby Husain ${ }^{4}$, See Z Hoe ${ }^{4}$ and Onn H Hashim 2,3

\begin{abstract}
Background: Proteins that are associated with hypertension may be identified by comparing the 2-dimensional gel electrophoresis (2-DE) profiles of the sera of spontaneously hypertensive rats (SHR) with those generated from normotensive Spraque-Dawley rats (SDR).

Results: Five proteins of high abundance were found to be significantly altered when the 2-DE serum profiles of the SHR were compared to those that were similarly generated from the SDR. Analysis by mass spectrometry and database search identified the proteins as retinol binding protein 4, complement C3, albumin (19.9 kDa fragment), alpha1 macroglobulin and alpha1 antiproteinase, which are all known to be associated with hypertension. The altered expression of the two latter proteins was found to be abrogated when similar analysis was performed on sera of the SHR that were treated with captopril.
\end{abstract}

Conclusion: Our data suggests that serum alpha1 macroglobulin and alpha1 antiproteinase are potentially useful complementary biomolecular indicators for monitoring of hypertension.

Keywords: hypertension, biomarker, spontaneously hypertensive rats, serum proteins, proteomics

\section{Background}

Spontaneously hypertensive rats (SHR) have been widely used as an animal model to investigate primary hypertension and its relationship to cardiovascular diseases. The SHR strain was generated in the 1960 s by Okamoto et al. by selective breeding of the Wistar-Kyoto rats with high blood pressure [1]. The blood pressure of SHR usually rises at around 5-6 weeks of age and the systolic pressure of an adult SHR may reach a value of between 180 and $200 \mathrm{mmHg}$. The SHR usually develops characteristics of cardiovascular diseases like hypertrophy of the heart and blood vessels, which start at around 40 weeks of age [2].

\footnotetext{
* Correspondence: hanizaaminudin@um.edu.my

'Institute of Biological Sciences, Faculty of Science, University of Malaya,

50603 Kuala Lumpur, Malaysia

Full list of author information is available at the end of the article
}

Hypertension has been known to cause the altered levels of serum or plasma proteins. A considerable number of proteins have been previously reported to be altered in levels in the sera of both animals and human subjects [3-6]. While some of the proteins were thought to be involved as anti-inflammatory and protective response $[4,7]$, others were related to endothelial vascular repair [5], arterial smooth muscle cell growth [6] and some may instead be the contributing factors of hypertension.

In the present study, we have investigated the simultaneous expression of the high abundant serum proteins in the normotensive Spraque-Dawley rats (SDR) and compared it with those expressed in the sera of SHR as well as the SHR that were treated with captopril.

\section{Ciomed Central}

(c) 2012 Aminudin et al; licensee BioMed Central Ltd. This is an Open Access article distributed under the terms of the Creative Commons Attribution License (http://creativecommons.org/licenses/by/2.0), which permits unrestricted use, distribution, and reproduction in any medium, provided the original work is properly cited. 
Table 1 Mean systolic blood pressure of control and captopril-treated rats

\begin{tabular}{lcc}
\hline Group & \multicolumn{2}{c}{ Systolic blood pressure $(\mathbf{m m H g})$} \\
\hline SDR & Day $\mathbf{1}$ & Day $\mathbf{1 0}$ \\
\hline SHR & $102 \pm 2.0$ & $103 \pm 3.4$ \\
\hline C-SHR & $197 \pm 6.8$ & $196 \pm 6.8$ \\
\hline
\end{tabular}

SDR - Sprague Dawley rats, SHR - spontaneously hypertensive rats, C-SHR captopriltreated SHR. Data are expressed as mean \pm S.E.M. Values of $p<0.05$ were considered significant.

\section{Results}

\section{Monitoring of rat blood pressure}

Table 1 demonstrates the blood pressure of control rats and those treated with $60 \mathrm{mg} / \mathrm{kg}$ body weight/day of captopril. The blood pressure of the control SDR rat group showed stable normal systolic pressure. The hypertensive group of rats (SHR) also showed an unchanged high level of systolic blood pressure. However, a significant reduction of the blood pressure was observed in the captopril-treated SHR.

\section{Profiling of rat serum samples}

Figure 1 demonstrates a typical representative 2-DE protein profile that was generated from a serum sample obtained from control non-treated SHR. Serum proteins were separated on the basis of their different $\mathrm{p} I \mathrm{~s}$ and molecular weights when subjected to 2-DE. Hundreds of highly-resolved protein spots were detected when the 2DE gels were silver-stained. Due to the broad dynamic range of proteins that are present in the serum, only the highly abundant proteins were detected by silver staining. Similar profiles were generated when serum samples of the SDR and captopril-treated SHR were subjected to 2-DE.

\section{Image analysis of rat serum proteins}

When image analysis was performed on the silverstained 2-DE gels generated using serum samples obtained from the SDR and compared to similar profiles generated from the SHR, the expression of 13 protein spots was initially found to be significantly altered $(p<$ $0.05)$. However, only five of the protein spots, i.e. 1,50 , 85,117 , and 211 , were truly altered when the $p$-values

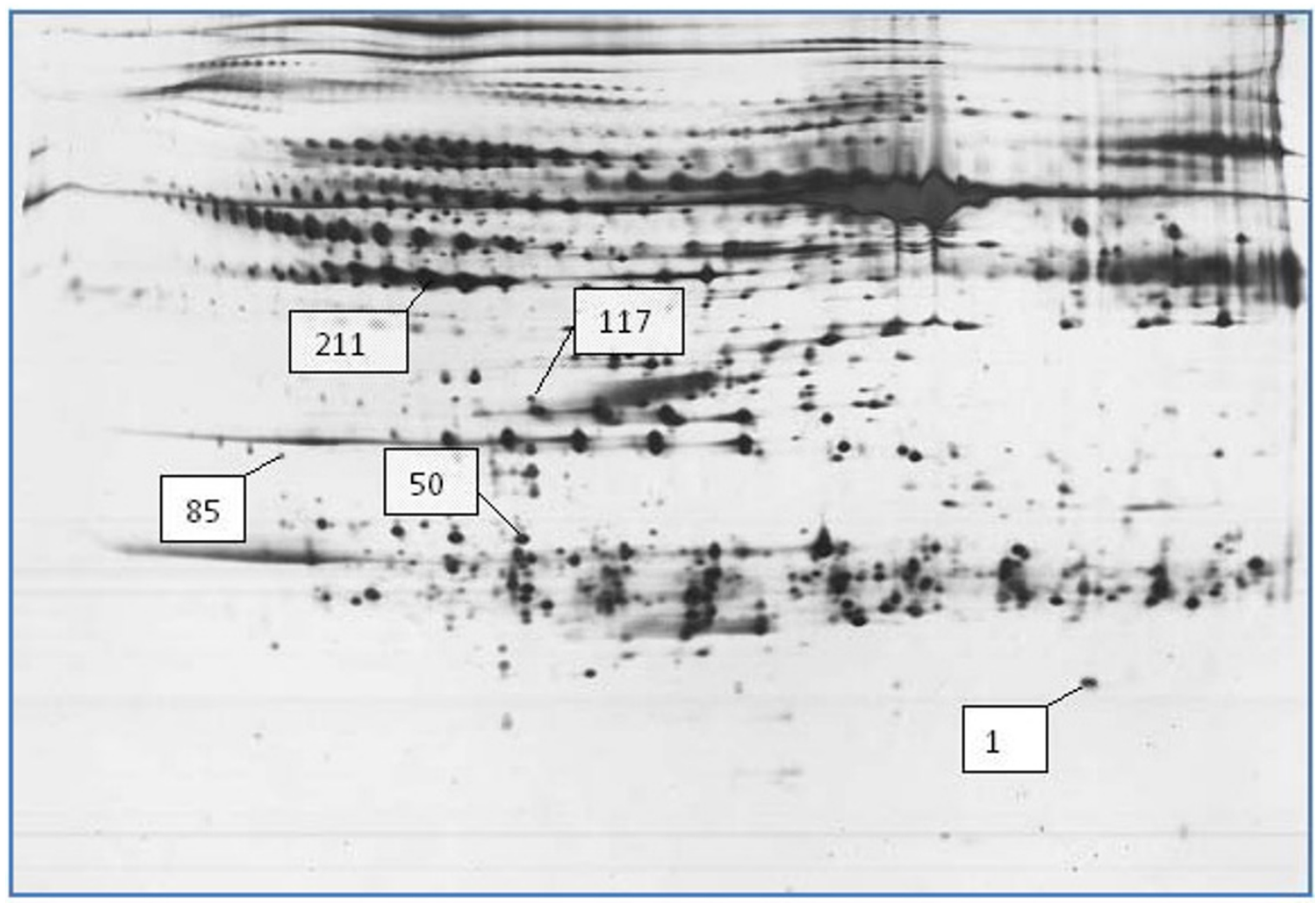

Figure 1 Image of a representative silver-stained 2-DE gel showing the high abundant proteins detected in an SHR serum. Spots 1, 50, 85,117 and 211 were significantly altered in levels when image analysis comparing the expression of 2-DE protein spots of SDR serum samples with those of the SHR. Acid side of the gel is to the left and relative molecular mass declines from the top. 
were corrected for false significant results using the method of Benjamini and Hochberg [8] (Figure 2). Using the serum proteins expressed in the sera of normotensive SDR as a standard reference, the levels of two proteins were found to be significantly lowered (spots 1 and 117) and three proteins (spots 50, 85 and 211) were apparently enhanced in the sera of the SHR. However, only spots 1,50 and 85 maintained to be significantly altered in levels when the serum 2-DE profiles of SHR that were treated with captopril were compared those of

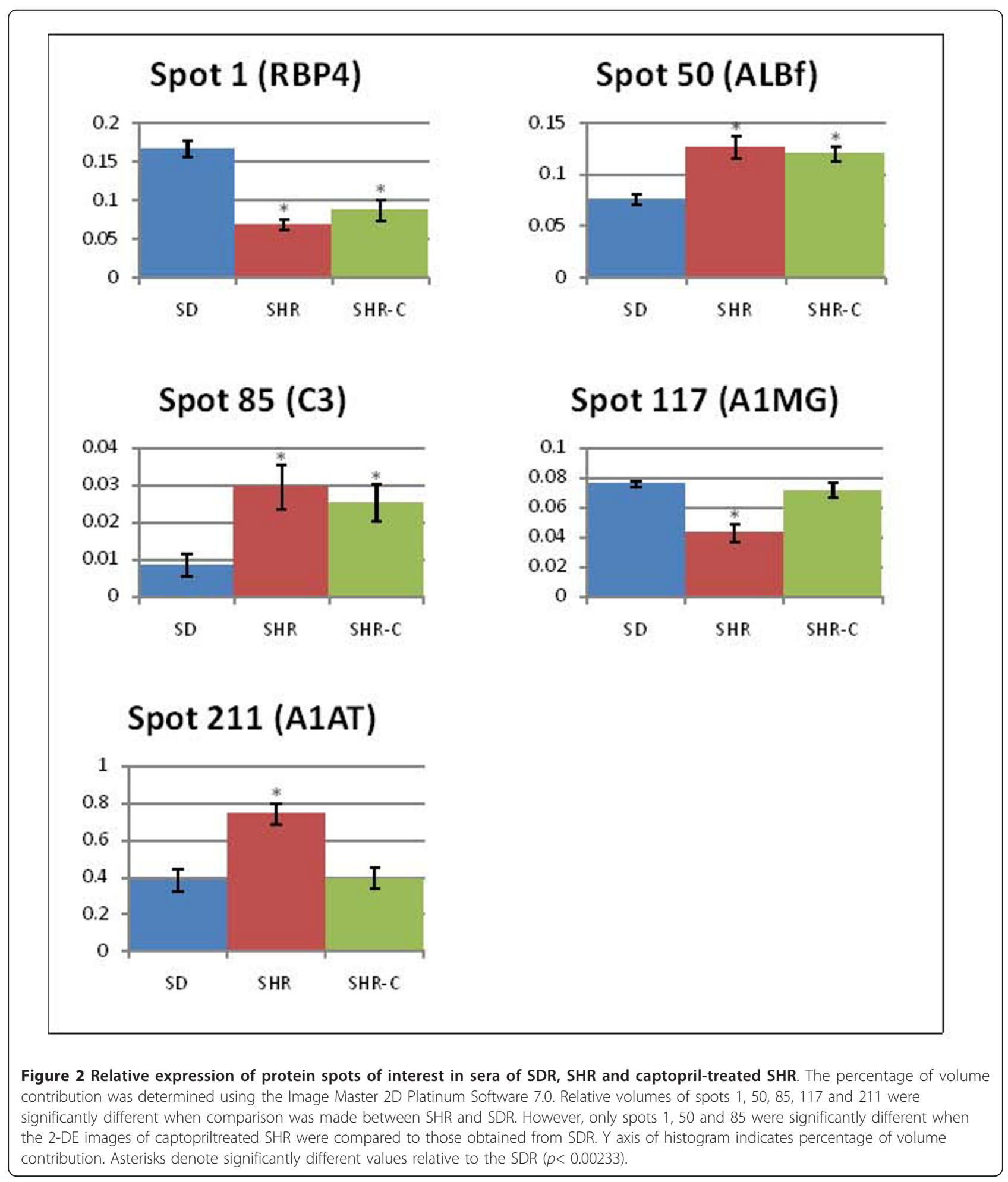


the normotensive SDR (Figure 2). The expression of spots 117 and 211 was apparently no longer significantly different and appeared to be normalised. Cropped images of the five serum protein spots in 2-DE gels of control and experimental rats are shown in Figure 3.

\section{Identification of differentially-expressed rat serum proteins}

The five differentially expressed protein spots were confidently identified by mass spectrometry using the 4800 Plus MALDI TOF/TOF analyzer and MASCOT database search (Table 2). They were retinol binding protein 4 (RBP4; spot 1), complement C3 (C3; spot 85), albumin (ALB; spot 50), alpha1 macroglobulin (A1MG; spot 117) and alpha 1 antiproteinase (A1AP; spot 211). The albumin spot was apparently resolved in the region of around $19.9 \mathrm{kDa}$ in the 2 -DE serum protein profiles, suggesting that it was a fragment of the protein (ALBf).

\section{Discussion}

In the present study, we firstly demonstrated a significant hypotensive effect of captopril following a 10-day treatment. This acute duration treatment showed a $20 \%$ hypotensive response, whereby the baseline blood pressure of $191 \mathrm{mmHg}$ was reduced to $151 \mathrm{mmHg}$ (Table $1)$. When the sera of SHR were subjected to 2-DE and

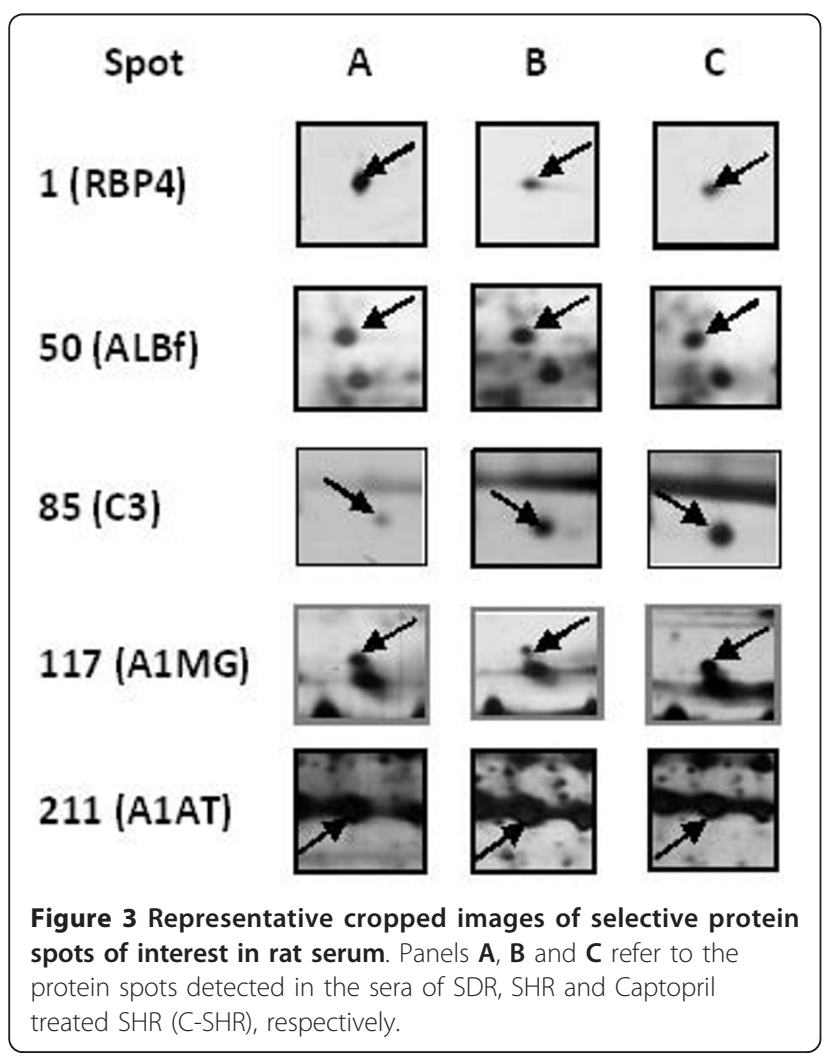

compared to similar profiles generated from those of SDR, the levels of five protein spots were found to be significantly altered. The spots were subsequently identified as those of the RBP4, C3, a $19.9 \mathrm{kDa}$ fragment of ALB, A1MG and A1AT (Table 2). All proteins have been previously identified to have some association with hypertension. The levels the proteins were earlier reported to be altered in the SHR as well as patients with hypertension, although the experiments were carried out on individual proteins. In this study, the different altered levels of the five serum proteins were detected simultaneously using the gel-based proteomics approach. Interestingly, the altered expression of A1MG and A1AT appeared to be abrogated in the SHR that were treated with captopril as their serum levels were no longer significantly different from those of the SDR.

RBP4 is responsible of delivering retinol to tissues [9]. Many studies have associated the serum/plasma protein with insulin resistance and diabetic complications $[10,11]$. RBP4 was reported to be elevated in patients with pregnancy-induced hypertension, possibly as a result of perturbed maternal glucose metabolism [12], and in women with hypertension caused by insulin resistance [13]. In contrast to these reports, our results demonstrated a significant reduction of RBP4 in both the non-treated and captopril-treated SHR groups. Treatment of the SHR with captopril did not appear to induce a significant change in the reduced serum levels of RBP4.

C3 is a complement component involved in both the humoral and innate immunity. The levels of C3 were found to be altered in the sera of patients with idiopathic pulmonary arterial hypertension [14], although the nature of this association is unclear. Studies performed by Lin et al. correlated the differential expression of C3 with the enhanced growth of arterial smooth muscle cells from SHR, prior to the development of hypertension [6]. C3 apparently mediates the arterial smooth muscle cell growth in the rats. The data of our study further confirms the altered levels of C3 in SHR. Like RBP4, however, the levels of C3 in the sera of SHR that were treated with captopril remains significantly different from that expressed in the SDR.

Serum ALB levels have been previously associated with hypertension. In an epidemiological investigation, increasing albumin concentration in the serum within the physiological range was found to correlate with the increase in systolic and diastolic blood pressure in men and women in all age groups [15]. However, the albumin spot that was significantly enhanced in both nontreated and captopril-treated SHR compared to SDR in our study appeared to be a $19.9 \mathrm{kDa}$ fragment of the serum protein. These fragments may be a result of the proteolysis of serum albumin, although currently no 
Table 2 Mass spectrometric identification of differentially expressed rat serum proteins

\begin{tabular}{lllllll}
\hline $\begin{array}{l}\text { Spot } \\
\text { ID }\end{array}$ & $\begin{array}{l}\text { Matched protein } \\
\text { identity }\end{array}$ & $\begin{array}{l}\text { Accession number (Swiss- } \\
\text { Prot) }\end{array}$ & $\begin{array}{l}\text { Theoretical mass } \\
(\mathrm{Da})\end{array}$ & $\begin{array}{l}\text { Theoretical } \\
\mathbf{p l}\end{array}$ & $\begin{array}{l}\text { MASCOT } \\
\text { score }\end{array}$ & $\begin{array}{l}\text { No. of peptides } \\
\text { matched }\end{array}$ \\
\hline 1 & RBP4 & P04916 & 23205 & 5.69 & 596 & 8 \\
\hline 50 & ALB & P02770 & 68686 & 6.09 & 82 & 10 \\
\hline 85 & C3 & P01026 & 186342 & 6.12 & 200 & 5 \\
\hline 117 & A1MG & P01023 & 167019 & 6.46 & 547 & 8 \\
\hline 211 & A1AT & P17475 & 46107 & 5.70 & 609 & 9 \\
\hline
\end{tabular}

Spot ID are as in Figure 1. RBP4, ALB, C3, A1MG and A1AT refer to retinol binding protein 4, albumin, complement C3, alpha1 macroglobulin and alpha1 antiproteinase, respectively. Accession numbers are from the MASCOT database (http://www.matrixscience.com).

information is available on the association of serum albumin with hypertension in rats.

A1MG, which is identical to the $\alpha 2$-macroglobulin that is present on the vascular endothelial cells in humans, binds to a group of serine proteases called tonins in rat tissues [16]. Tonin acts on angiotensin I (Ang I), as well as angiotensinogen (AG) and other peptides presenting the $\mathrm{N}$-terminal sequence of $\mathrm{AG}$ to form the vasoconstrictor peptide, angiotensin II (Ang II). The tonin- $\alpha_{1}$-macroglobulin complex can generate Ang II from Ang I despite complete inhibition of the Ang I converting enzyme [17]. Studies have demonstrated the capability of tonin to release bradykinin directly, thus suggesting that the protease is involved in the kinintensin system that generates both the pressor (AngII) and depressor (bradykinin) [18]. When taken together, these findings suggest that A1MG may play a role in the regulation of blood pressure. In the present study, the low levels of A1MG detected in the SHR compared to SDR provide some explanation for the increase in blood pressure in the SHR. The lowered levels were apparently normalised when the SHR were treated with captopril, which indicates an inverse correlation of the serum A1MG levels with hypertension.

A1AT is a serine protease inhibitor (serpin) that functions as an antitrypsin as well as an antithrombin [19]. Its primary target includes elastase, plasmin and thrombin. A1AT protects the connective tissues (elastin) from inflammatory enzymes such as elastase in the lungs and pulmonary system, as well as helps to prevent blood coagulation. Levels of the serum acute-phase protein were shown to correlate positively with blood pressure in humans [4].

Similarly, our results indicated that the levels of A1AT were increased in the sera of SHR compared to SDR, suggesting an acute-phase response to the increase of blood pressure in the SHR. Treatment of the SHR with captopril appeared to demonstrate an apparent abrogation of the altered levels of A1AT in sera of the rats, which further suggests a direct correlation of A1AT levels with hypertension.

\section{Conclusion}

Taken together, our data appear to indicate that hypertension causes the different altered expression of RBP4, C3, ALBf, A1MG and A1AT in the rat serum and that the altered levels of the two latter proteins were apparently normalized when the rats were treated with captopril. Unlike the previous results of others that showed similar altered levels of proteins individually, our proteomics analysis was able to demonstrate the altered levels of the proteins simultaneously in the rat serum samples. Together, these proteins have the potential to be used as indicators for monitoring of hypertension and its adverse consequences.

\section{Materials and methods \\ Rat}

SHR and SDR aged between 8-10 weeks (weighing 250$320 \mathrm{~g}$ ) were used throughout the study. In this study, the SDR was used as control normotensive rats as they are less prone to hypertension compared to the WKY. All rats were singly caged and housed under environmentally controlled conditions with 12 hours of light and dark cycles and free access to pellet and water ad libidum at the Animal House, Faculty of Medicine, University of Malaya. All treatments were performed according to the standard recommended procedure described in the Helsinki declaration.

\section{Treatment with captopril}

Captopril was solubilised in distilled water $(60 \mathrm{mg} / \mathrm{kg}$ body weight) and provided to a group of SHR $(n=6)$ daily for 10 consecutive days in the form of drinking solution $(30 \mathrm{ml}$ per rat/day). Untreated SHR $(\mathrm{n}=6)$ and SDR $(n=6)$ received tap water for drinking. Captopril treated rats will only received normal tap water once the $30 \mathrm{ml}$ dosage has been fully consumed.

\section{Monitoring of indirect blood pressure}

Baseline blood pressure was measured on the first (day 1) and further monitored on the last day of treatment (day 10). Systolic blood pressure was assessed on 
preheated conscious rat by tail-cuff method using a noninvasive blood pressure controller coupled to a Powerlab system (AD Instuments Pty Ltd, NSW, Australia). Blood samples were drawn from the rats on the $11^{\text {th }}$ day and sera were obtained by centrifugation of the blood at $4^{\circ} \mathrm{C}$. Serum samples were stored in aliquots at $-20^{\circ} \mathrm{C}$, prior to the experiments.

\section{Two-dimensional electrophoresis}

Two-dimensional electrophoresis (2-DE) was performed as previously described [20]. Serum samples, each containing $100 \mathrm{mg}$ of protein (estimated using BCA ${ }^{\mathrm{TM}}$ Protein Assay Kit), were mixed with $450 \mu \mathrm{l}$ rehydration solution containing $8 \mathrm{M}$ urea, $2 \% \mathrm{w} / \mathrm{v}$ CHAPS, $0.5 \% \mathrm{v} / \mathrm{v}$ IPG buffer, $0.002 \% \mathrm{w} / \mathrm{v}$ bromophenol blue and $10 \% \mathrm{w} / \mathrm{v}$ DTT for $30 \mathrm{~min}$ at room temperature. The mixtures were then centrifuged at $1000 \mathrm{rpm}$ for $5 \mathrm{~min}$. The samples were subjected to isoelectric focusing in $24 \mathrm{~cm}$ rehydrated precast Immobilline Drystrips at $\mathrm{pH}$ 4-7 (GE Healthcare Biosciences, Uppsala, Sweden). For the second dimension, focused samples in the strips were subjected to electrophoresis using $11 \%$ polyacrylamide gel in presence of SDS.

\section{Staining of 2-DE gels}

Gels were silver-stained using the protocol described by Heukeshoven and Dernick [21]. A modified silver staining approach was used for gels analysed by mass spectrometry [22].

\section{Image analysis}

Silver-stained gels were scanned using the ImageScanner III. Analysis of serum protein spot volume was performed using the ImageMaster Platinum 7.0 software (GE Healthcare Biosciences, Uppsala, Sweden). Percentage of spot volume contribution refers to the spot volume of a protein expressed as a percentage of the total spot volume of all detected proteins. Results obtained from proteins that were expressed in sera of SDR were used as standard references for comparative purposes.

\section{Sample preparation for mass spectrometry}

Samples were prepared as previously described [23]. Protein spots were manually excised from gels and kept in clean microfuge tubes containing small volumes of Milli-Q water to keep them hydrated. The gel plugs were destained using $15 \mathrm{mM}$ potassium ferricyanide in $50 \mathrm{mM}$ sodium thiosulphate and further reduced and alkylated using $10 \mathrm{mM}$ dithiothreitol and $55 \mathrm{mM}$ iodoacetamide in $100 \mathrm{mM}$ ammonium bicarbonate, respectively. Following thorough washings with 50\% acetonitrile $(\mathrm{ACN})$ in $100 \mathrm{mM}$ ammonium bicarbonate and $100 \% \mathrm{ACN}$, the gel plugs were dehydrated using vacuum centrifugation. The dried plugs were then incubated in $30 \mu \mathrm{l}$ of $7 \mathrm{ng} / \mu \mathrm{l}$ trypsin in $40 \mathrm{mM}$ ammonium bicarbonate in $10 \% \mathrm{ACN}$ solution at $37^{\circ} \mathrm{C}$ overnight. Peptides were finally extracted using $50 \%$ and $100 \%$ $\mathrm{ACN}$ and subsequently dried using a vacuum centrifuge.

\section{Mass spectrometry}

Dried peptides were reconstituted with $0.1 \%$ formic acid and desalted using ZipTip C18 (Millipore, Billerica, USA) according to the protocol described by the manufacturer. The final elution volume following ZipTip cleanup was then mixed with an equal volume of matrix consisting of a saturated solution of $\alpha$-cyano-4-hydroxycinnamic acid (Sigma Chemical Co., St. Louis, USA) prepared in $50 \% \mathrm{ACN} / 0.1 \%$ TFA. Each sample was immediately spotted $(0.7 \mu \mathrm{l})$ onto a stainless-steel sample target plate. The samples were analyzed using the 4800 Plus MALDI TOF/TOF analyzer (Applied Biosystem/MDS Sciex, Toronto, Canada), with the mass standard kit serving as the calibrator for the resulting MS and MS/MS mass spectra scales.

\section{Protein identification}

Data obtained from the MS/MS analysis was generated using peaklist software 4000 Series Explorer (release version 3). The data was exported for search using the MASCOT search engine (Matrix Science, London, UK; release version 2.2) against Rodentia entries in the NCBI non-redundant database. Database parameters used were: enzyme/trypsin; one missed cleavage allowed; fixed modification/carbamidomethyl (cysteine); variable modification/oxidation (methionine); mass tolerance for precursor ion/peptide tolerance: $50 \mathrm{ppm}$ and mass tolerance for fragment ion/MS/MS tolerance: $0.1 \mathrm{Da}$. The cut-off score for accepting individual MS/MS spectra was set at .29 for homology and .38 for matched identity.

\section{Statistical analysis}

ANOVA was used to analyze the significance of differences between SDR, captopril-treated and non-treated SHR. All values are presented as mean \pm S.E.M (standard error of the mean). The false discovery rate control was performed using the method of Benjamini and Hochberg [8]. After correction, $p$ values of less than 0.00233 were considered significant.

\section{Acknowledgements}

The authors wish to thank Ms Nur Fasihah Yahaya, Ms Nurul Syamimi Salleh, Dr Puteri Shafinaz Akmar and Mr Poh Tin Fong for their technical contribution. This study was financially supported by the Ministry of Science, Technology and Innovation (EScience, 0201-03-SF2048) and the University of Malaya Postgraduate Research Grant (PS 172/2009A). 


\section{Author details}

'Institute of Biological Sciences, Faculty of Science, University of Malaya, 50603 Kuala Lumpur, Malaysia. ${ }^{2}$ University of Malaya Centre for Proteomics Research, University of Malaya, Kuala Lumpur, Malaysia. ${ }^{3}$ Department of Molecular Medicine, Faculty of Medicine, University of Malaya, Kuala Lumpur, Malaysia. ${ }^{4}$ Department of Physiology, Faculty of Medicine, University of Malaya, Kuala Lumpur, Malaysia.

\section{Authors' contributions}

NA planned the study and drafted the manuscript; NAHA and HM carried out the experiments and analyzed the data; SAK provided advice on mass spectrometry analysis; $\mathrm{OHH}$ contributed to the design of the study and critically revised the manuscript; $\mathrm{RH}$ and $\mathrm{SZH}$ assisted in the measurement of rat blood pressure. All authors read and approved the final manuscript.

\section{Competing interests}

The authors declare that they have no competing interests.

Received: 17 August 2011 Accepted: 15 March 2012

Published: 15 March 2012

\section{References}

1. Okamoto AK, Aoki K: Development of a strain of spontaneously hypertensive rat. Jap Circ J 1963, 27:282-293.

2. Conrad CH, Brooks WW, Hayes JA, Sen S, Robinson KG, Bing OH: Myocardial fibrosis and stiffness with hypertrophy and heart failure in the spontaneously hypertensive rat. Circulation 1995, 91:161-170.

3. Cloix JF, Devynck MA, Brentano JL, Meyer P: Plasma protein changes in primary hypertension in humans and rats. Hypertension 1983, 5:128-134.

4. Engström G, Hedblad B, Janzon L, Lindgärde F: Fatality of acute coronary events in relation to hypertension and low-grade inflammation: a population-based cohort study. J Hum Hypertension 2006, 20:581-586.

5. Kiga C, Sakurai H, Goto H, Hayashi K, Shimada Y, Saiki I: Proteomic identification of haptoglobin as a stroke plasma biomarker in spontaneously hypertensive stroke-prone rats. Life Sci 2008, 83:625-631.

6. Lin ZH, Fukuda N, Jin XQ, Yao EH, Ueno T, Endo M, Saito S, Matsumoto K, Mugishima H: Complement 3 is involved in the synthetic phenotype and exaggerated growth of vascular smooth muscle cells from spontaneously hypertensive rats. Hypertension 2004, 44:42-47.

7. Boos CJ, Lip GYH: Is Hypertension an Inflammatory Process? Curr Pharm Des 2006, 12:1623-1635.

8. Benjamini $Y$, Hochberg $Y$ : Controlling the false discovery rate: a practical and powerful approach to multiple testing. J R Stat Soc B 1995, 57:289-300.

9. Quadro L, Blaner WS, Salchow DJ, Vogel S, Piantedosi R, Gouras P, Freeman S, Cosma MP, Colantuoni V, Gottesman ME: Impaired retinal function and vitamin A availability in mice lacking retinol-binding protein. EMBO J 1999, 18:4633-4644.

10. Yang Q, Graham TE, Mody N, Preitner F, Peroni OD, Zabolotny JM, Kotani K, Quadro L, Kahn BB: Serum retinol binding protein 4 contributes to insulin resistance in obesity and type 2 diabetes. Nature 2005, 436:356-362.

11. Takebayashi K, Suetsugu M, Wakabayashi S, Aso Y, Inukai T: Retinol binding protein-4 levels and clinical features of type 2 diabetes patients. $J$ Clin Endocrinol Metab 2007, 92:2712-2719.

12. Inoue S, Takamoto N, Akahori Y, Masumoto A, Nakatsukasa H, Msuyama $\mathrm{H}$, Hiramatsu Y: Elevated level of serum retinol-binding protein 4 in pregnancy-induced hypertension. J Obstet Gynaecol Res 2009, 35:293-300.

13. Solini A, Santini E, Madec S, Rossi C, Muscelli E: Retinol-binding protein-4 in women with untreated essential hypertension. Am J Hypertens 2009, 22:1001-1006.

14. Zhang J, Zhang Y, Li N, Liu Z, Xiong C, Ni X, Pu Y, Hui R, He J, Pu J: Potential diagnostic biomarkers in serum of idiopathic pulmonary arterial hypertension. Respir Med 2009, 103:1801-1816.

15. Høstmark AT, Tomten SE, Berg JE: Serum albumin and blood pressure: a population-based, cross-sectional study. J Hypertens 2005, 23:725-730.

16. Tremblay J, Thibault G, Gutkowska J, Boucher R, Genest J: Purification and partial characterization of a plasma inhibitor of tonin. Can J Biochem 1981, 59:256-261.

17. Ikeda M, Sasaguri M, Maruta $H$, Arakawa K: Formation of angiotensinogen II by tonin-inhibitor complex. Hypertension 1988, 11:63-70.
18. Ikeda M, Arakawa K: Kininogenase activity of tonin. Hypertension 1984, 6:222-228.

19. Gettins PG: Serpin structure, mechanism and function. Chem Rev 2002 102:4751-4804.

20. Doustjalali SR, Yusof Y, Yip CH, Looi LM, Pillay B, Hashim OH: Aberrant expression of acute-phase reactant proteins in sera and breast lesions of patients with malignant and benign breast tumors. Electrophoresis 2004, 25:2392-2401.

21. Heukeshoven J, Dernick R: Improved silver staining procedure for fast staining in PhastSystem Development Unit. I. Staining of sodium dodecyl sulfate gels. Electrophoresis 1988, 9:28-32.

22. Yan JX, Wait R, Berkelman T, Harry RA, Westbrook JA, Wheeler CH, Dunn MJ: A modified silver staining protocol for visualization of proteins compatible with matrix-assisted laser desorption/ionization and electrospray ionization-mass spectrometry. Electrophoresis 2000, 21:3666-3672

23. Seriramalu R, Pang WW, Jayapalan JJ, Mohamed E, Abdul-Rahman PS, Bustam AZ, Khoo ASB, Hashim OH: Application of champedak mannosebinding lectin in the glycoproteomic profiling of serum samples unmasks reduced expression of alpha- 2 macroglobulin and complement factor B in patients with nasopharyngeal carcinoma. Electrophoresis 2010, 31:2388-2395

doi:10.1186/1477-5956-10-17

Cite this article as: Aminudin et al:: Treatment with captopril abrogates the altered expression of alpha1 macroglobulin and alpha1 antiproteinase in sera of spontaneously hypertensive rats. Proteome Science 2012 10:17.

\section{Submit your next manuscript to BioMed Central and take full advantage of:}

- Convenient online submission

- Thorough peer review

- No space constraints or color figure charges

- Immediate publication on acceptance

- Inclusion in PubMed, CAS, Scopus and Google Scholar

- Research which is freely available for redistribution

Submit your manuscript at www.biomedcentral.com/submit
Ciomed Central 